\title{
PREDIKSI MINAT MAHASISWA UNTUK BERWIRAUSAHA MENGGUNAKAN PENDEKATAN THEORY OF PLANNED BEHAVIOR
}

\author{
Ratna Listiana Dewanti ${ }^{1)}$ \\ Taufik Bin Abad ${ }^{2}$ \\ ${ }^{1}$ Fakultas Bisnis dan Teknologi Informasi, Universitas Teknologi Yogyakarta \\ e-mail: ratna.listiana@gmail.com \\ ${ }^{2}$ Fakultas Bisnis dan Teknologi Informasi, Universitas Teknologi Yogyakarta \\ e-mail: abad.taufik@yahoo.co.id
}

\begin{abstract}
This research aims to identify factors that influence the students' motivation to run business based on theory of planned behavior. This research is conducted by examining the influence of students' attitude againts its behavior, subjective norms and behavioral control on their intention to run business. The research samples are students of private university majoring in management because they have subject on Entrepreneur in the curriculum and for the reason of convenience. Research data are collected by distributing questionnaire to the students. Regression analysis is applied to analize 167 questionnaires sent back by the respondents. The result shows that the students' attitude againts the behavior does not influence the intention to run business. While students'attitude againts subjective norms and behavioral control do influence the intention to run business.
\end{abstract}

Keywords: student behavior, subjective norms, behavior control

\section{PENDAHULUAN}

Banyaknya pengangguran terdidik di Indonesia tergolong tinggi. Angka pengangguran pemuda terdidik mencapai 47,81 persen dari total angka pengangguran nasional. Perguruan tinggi mempunyai peran yang penting dalam membangun kemandirian lulusannya (Ranto, 2011). Peran penting dalam membentuk kemandirian dapat dilakukan secara terstruktur dengan cara memberikan materi perkuliahan yang dapat mendorong atau membentuk jiwa kewirausahaan. Salah satu upaya yang dapat dilakukan adalah dengan menyelenggarakan kuliah kewirausahaan dan kegiatan kewirausahaan yang dapat membantu mahasiswa untuk mempunyai wawasan mengenai kemandirian dalam pekerjaan.

Untuk berwirausaha diperlukan keberanian untuk memulai, menanggung resiko dan kemampuan mengelola usaha. Selain itu dalam berwirausaha, pelaku dituntut untuk memiliki kemampuan kreatif dan inovatif yang dijadikan dasar, kiat dan sumber daya untuk mencari peluang supaya usaha selalu berkembang. Kewirausahaan adalah kemampuan untuk menciptakan sesuatu yang baru dan berbeda melalui kreatifitas dan inovasi untuk menciptakan peluang usaha. Mata kuliah kewirausahaan yang diselengggarakan perguruan tinggi, harus membekali mahasiswa untuk mampu mandiri, baik kemampuan softskill terkait motivasi, semangat, penerapan nilai-nilai wirausaha maupun kemampuan hardskill seperti kemampuan akses modal dan teknis pengembangan produk atau jasa. Kurikulum kewirausahaan yang demikian memang akan sulit diciptakan dan juga diterapkan, mengingat lingkungan yang dihadapi seorang wirausaha bukan merupakan lingkungan 
yang statis. Sangat mungkin materi kuliah yang diberikan saat mahasiswa kuliah akan sangat berbeda dengan realitas yang dihadapi mahasiswa pada saat dia berwirausaha. Disadari bahwa pengetahuan dan ketrampilan saja hanya memenuhi syarat minimal untuk hidup sebagai seorang wirausaha. Minat menjadi wirausaha merupakan faktor yang menentukan apakah seorang yang telah mendapatkan pengetahuan dan ketrampilan untuk berwirausaha mewujudkan dirinya sebagai wirausaha. Menakar minat seseorang menjadi wirausaha menjadi krusial dilakukan agar upaya peningkatan pengetahuan dan ketrampilan dapat diwujudkan menjadi suatu bisnis yang riil.

Faktor minat dan perilaku dapat dijelaskan oleh Theory of Planned Behavior. Teori tersebut merupakan pengembangan dari theory of reasoned action, yaitu teori yang digunakan untuk memprediksi minat dan perilaku. Berdasarkan teori tersebut minat dipengaruhi oleh persepsi seseorang terhadap suatu bentuk keinginan. Minat yang pada akhirnya mempengaruhi perilaku seseorang didorong oleh berbagai faktor. Theory of planned behavior mengutamakan adanya tiga determinan niat yang sifatnya independen secara konseptual yaitu sikap terhadap perilaku, norma subjektif dan persepsi terhadap kontrol keperilakuan (Perceived Behavior Control). Secara umum dapat dikatakan bahwa semakin baik sikap dan norma subjektif terhadap perilaku berwirausaha, maka semakin kuat minat seseorang untuk berwirausaha. Dalam hal ini minat berwirausaha dipandang sebagai variabel penentu berperilaku sesungguhnya, artinya semakin kuat minat seseorang untuk berwirausaha maka semakin besar pula keberhasilan prediksi perilaku tersebut terjadi. Niat terutama mencerminkan kemauan seseorang untuk melakukan tindakan tertentu. Sedangkan kontrol yang dirasakan sangat memperhatikan sumber peluang yang mungkin ada. Jadi ada perbedaan antara faktor motivasional dan kontrol yang dirasakan. (Dharmmesta, 1998 dalam Ranto, 2011).

Theory of Planned Behavior menjelaskan sikap, norma subjektif dan kontrol keperilakuan yang dirasakan sebagai variabel yang mendahului niat dan perilaku. Berdasarkan penjelasan-penjelasan tersebut, maka penelitian ini akan menguji pengaruh sikap, norma subjektif dan kontrol keperilakukan terhadap minat berwirausaha dan perilaku berwirausaha itu sendiri.

Permasalahan dalam penelitian ini adalah seberapa tinggi minat mahasiswa untuk berwirausaha. Pengukuran tingkat minat berwirausaha dilakukan dengan mengaplikasikan theory of planned behavior yang memasukkan sikap, norma subjektif dan kontrol keperilakuan sebagai faktor yang menentukan besaran minat seseorang. Apabila diketahui minat mahasiswa untuk berwirausaha maka dapat dirumuskan kurikulum yang tepat agar mahasiswa lebih termotivasi untuk berwirausaha setelah mengikuti mata kuliah kewirausahaan. Sehingga penelitian ini akan menganalisis apakah sikap, norma subjektif dan kontrol keperilakuan mempengaruhi minat mahasiswa untuk berwirausaha.

Theory of planned behavior merupakan pengembangan dari theory of reasoned action yang muncul sebagai alternatif untuk memprediksi perilaku secara lebih akurat, seperti penelitian yang dilakukan Ajzen (1987, 1988, 1989). Theory of reasoned action dan theory of planned behavior tidak bertentangan satu sama lain. Untuk memprediks iminat, selain dari sikap dan norma subjektif ditambah variabel baru yaitu kontrol keperilakuan (perceived behavioural control). 


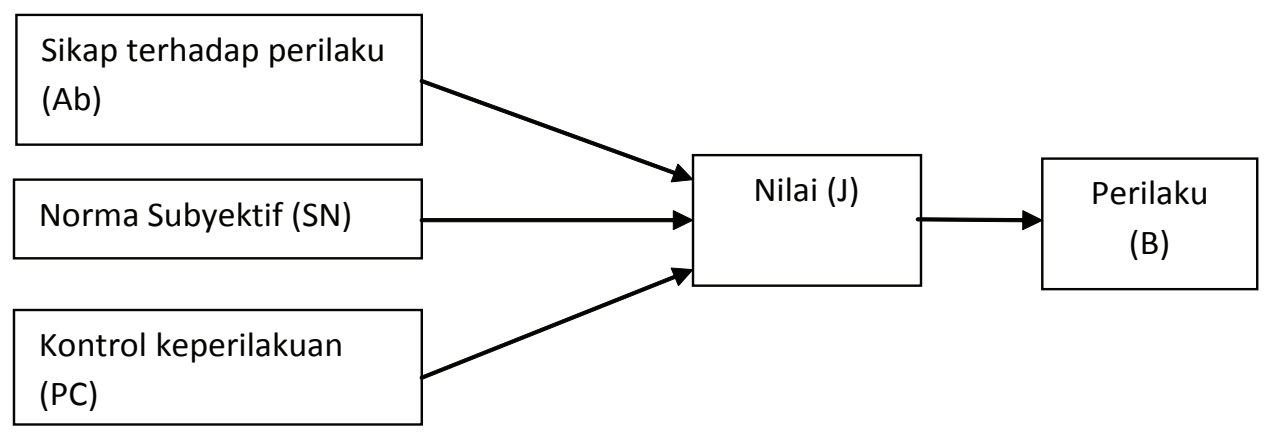

Gambar 1. Theory of Planned Behavior

Konsep atau variabel-variabel dan keterkaitannya masing-masing teori dapat dilihat pada Gambar 1. Hubungan dan pengaruh yang terlihat dengan tanda panah solid pada gambar tersebut menggambarkan theory of reasoned action.

Theory of planned behavior mengutamakan adanya tiga deteminan niat yang bersifat independen secara konseptual, yaitu (Ranto, 2011):

a. Sikap terhadap perilaku yang menunjukkan tingkat dimana seseorang mempunyai evaluasi yang baik atau kurang baik terhadap perilaku tertentu.

b. Normal subjektif sebagai faktor sosial yang menunjukkan tekanan sosial yang dirasakan untuk melakukan atau tidak melakukan tindakan atau perilaku.

c. Kontrol keperilakuan yang dirasakan (perceived behavior control), menunjukkan mudahnya atau sulitnya melakukan tindakan dan dianggap sebagai cerminan pengalaman masa lalu disamping halangan yang terantisipasi.

Secara umum dapat dikatakan bahwa semakin baik sikap dan norma subjektif terhadap suatu perilaku beli dan semakin besar kontrol keperilakuan yang dirasakannya, maka semakin kuat niat seseorang tersebut untuk melakukan kegiatan yang dimaksud. Sebaiknya niat dipandang sebagai satu variabel penentu berperilaku sesungguhnya, artinya semakin kuat niat seseorang untuk berwirausaha, semakin besar pula keberhasilan prediksi perilaku atau tujuan keperilakuan tersebut untuk terjadi. Akan tetapi, tingkat keberhasilan tersebut akan bergantung tidak hanya pada niat, tetapi juga pada faktorfaktor nonmotivasional seperti adanya peluang dan sumber (misalnya: waktu, uang, keterampilan, kerjasama dari orang lain, dan sebagainya) (Dharmmesta, 1998).

Theory of planned bahavior menjelaskan sikap, norma subjektif, dan kontrol keperilakuan yang dirasakan sebagai variabel yang mendahului niat dan perilaku. Pada dasarnya teori tersebut mendalilkan bahwa perilaku itu merupakan fungsi dari informasi penting, atau keyakinan penting yang relevan dengan perilaku tersebut.

Kewirausahaan saat ini merupakan sebuah alternatif yang dapat dijadikan solusi bagi penyelesaian permasalahan sempitnya lapangan pekerjaan. Memberikan bekal kewirausahaan kepada mahasiswa merupakan salah satu upaya membangun kemandirian mahasiswa. Disadari betul bahwa jumlah lulusan perguruan tinggi setiap tahunnya meningkat dan tidak semua lulusan tersebut dapat terserap oleh dunia kerja, sehingga memberikan pemahaman yang jelas tentang bagaimana pentingnya berwirausaha itu kepada mahasiswa menjadi hal yang sangat penting, karena disamping menolong diri sendiri dapat membantu orang lain dalam menciptakan lapangan kerja baru dalam berbagai sektor (Ranto, 2011). 
Munculnya minat mahasiswa untuk berwirausaha tentunya harus dapat di stimulus oleh berbagai kegiatan yang ada di kampus. Oleh sebab itu peran kampus menjadi sangat penting (Ranto, 2011). Berbagai kegiatan kewirausahaan dapat dimunculkan sebagai langkah mendekatkan dunia kewirausahaan, sehingga diharapkan semangat berwirausaha dapat muncul.

Terwujudnya mahasiswa yang mandiri dan mampu berkarya dibutuhkan beberapa sifat yang harus dimilikinya, diantaranya adalah: Pertama; sikap berani. Kedua; Memiliki kreatifitas (Ranto, 2011). Selain menonjolkan sikap berani, para wirausahawan juga unggul dalam daya kreatif, inspirasi, imajinasi dan kemampuan yang cukup tinggi untuk menyesuaikan diri dengan perkembangan.

Aplikasi Theory of Planned Behavior pada penelitian sikap dan niat telah dilakukan oleh Zaiyad dan Tjahjono (2007). Penelitian yang dilakukan adalah tentang sikap dan niat siswa-siswi SMA swasta Yogyakarta untuk melanjutkan studi di sebuah Perguruan Tinggi Swasta di Yogyakarta, menunjukkan hasil bahwa secara serentak variabel sikap, norma subjektif dan kontrol keperilakuan berpengaruh signifikan terhadap niat. Sedangkan secara parsial variabel sikap tidak menunjukkan pengaruh yang signifikan, untuk norma subjektif dan kontrol keperilakuan mempunyai pengaruh yang signifikan terhadap niat siswa untuk melanjutkan studi pada salah satu Perguruan Tinggi Swasta di Yogyakarta. Penelitian lain pernah dilakukan oleh Ranto (2011) yang meneliti mengenai minat berwirausaha mahasiswa di PTS Yogyakarta. Penelitian Ranto (2011) menyatakan bahwa sikap, norma subjektif dan kontrol keperilakuan mempengaruhi minat mahasiswa untuk berwirausaha. Penelitian ini merupakan replikasi dari penelitian Ranto (2011). Replikasi dilakukan dengan menambah objek yaitu pada mahasiswa program studi manajemen, baik yang sudah mengambil mata kuliah kewirausahaan maupun mahasiswa yang belum mengambil mata kuliah kewirausahaan. Kedua kelompok responden tersebut akan diuji secara terpisah untuk dibandingkan tinggi rendahnya minat.

Konsep pengaruh sikap, norma subjektif dan kontrol keperilakuan terhadap niat berwirausaha pada Mahasiswa Perguruan Tinggi Swasta di Yogyakarta dapat digambarkan sebagai berikut:

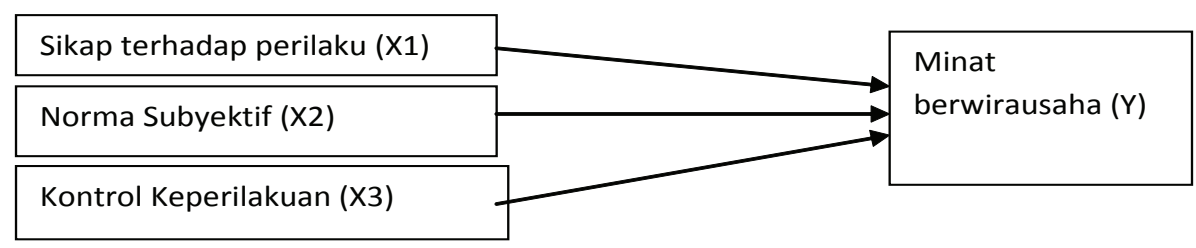

Gambar 2. Model Penelitian

Model tersebut dapat dijelaskan sebagai berikut:

a. Mahasiswa yang mempunyai evaluasi yang baik terhadap minat berwirausaha, maka dia mempunyai persepsi bahwa berwirausaha itu baik untuk kehidupannya di masa yang akan datang. Sikap mahasiswa yang berpandangan bahwa perilaku berwirausaha menjanjikan kehidupan yang lebih baik dibandingkan dengan profesi yang lain, maka minat mahasiswa untuk berwirausaha akan semakin tinggi.

b. Mahasiswa yang mempunyai lingkungan dimana profesi sebagai wirausaha merupakan profesi pilihan, maka mahasiswa tersebut akan mempunyai norma subjektid bahwa pilihannya adalah berwirausaha. Mahasiswa yang berada dalam 
lingkungan wirausaha yang luas, maka minatnya untuk berwirausaha juga semakin tinggi. Berdasarkan uraian ini, maka dirumuskan hipotesis:

c. Mahasiswa yang menganggap bahwa berwirausaha adalah profesi yang mudah untuk dilakukan maka dia akan mempunyai minat untuk berwirausaha. Semakin mudah persepsi mahasiswa terhadap profesi wirausaha, maka semakin tinggi minatnya untuk berwirausaha.

\section{METODE PENELITIAN}

Penelitian dilakukan dengan cara penyebaran kuesioner untuk mendapatkan data penelitian. Data penelitian berupa pendapat mahasiswa mengenai minatnya untuk berwirausaha. Kuesioner disebarkan langsung oleh asisten peneliti ke mahasiswa PTS yang ada di Yogyakarta. Data yang diperoleh kemudian di tabulasi untuk memudahkan proses olah data. Kuesioner menanyakan tentang variabel penelitian yang meliputi: Minat mahasiswa untuk Berwirausaha, Sikap terhadap Perilaku, Norma Subyektif dan Kontrol Keperilakuan.

Variabel minat dapat diukur dengan merumuskan pernyataan yang menunjukkan sesuatu yang akan dilakukan atau suatu estimasi perilaku. Variabel ini diukur dengan satu pernyataan kesetujuan mahasisa terhadap minat berwirausaha. Ukuran menggunakan skala likert 1 sampai 5.

Sikap terhadap perilaku menjelaskan pendapat responden mengenai sikap yang akan diambil apabila mahasiswa berwirausaha. Sikap terhadap perilaku ditanyakan dengan pendapat responden terhadap keyakinan untuk berwirausah dan akibat dari keyakinan tersebut. Sikap terhadap perilaku merupakan penjumlahan hasil perkalian keyakinan memilih dengan evaluasi akibat.

Prosedur pengukuran sikap terhadap perilaku dapat diukur dalam dua pernyataan (Dharmmesta, 1998). Pernyataan pertama menyatakan keyakinan dalam memilih minat wirausaha (bi). Pernyataan kedua merupakan evaluasi terhadap pemilihan pada pernyataan pertama (ei). Dua pernyataan tersebut diukur dengan menggunakan skala likert 1 sampai 5.

Norma subjektif menanyakan pendapat mahasiswa tentang wirausaha. Norma subjektif juga menanyakan apakah keyakinan mahasiswa terhadap profesi wirausaha dipengaruhi oleh lingkungan. Norma subjektif merupakan penjumlahan hasil perkalian antara keyakinan normatif dengan kemauan mengikuti saran orang penting seperti keluarga dan teman. Prosedur pengukuran norma subjektif juga dapat diukur dalam dua pernyataan (Dharmmesta, 1998). Pernyataan pertama mengenai keyakinan normatife mahasiswa (Nbi) dan pernyataan kedua mengenai sikap mahasiswa terhadap saran orang penting di sekitarnya (Mci). Kedua pernyataan menggunakan skala likert 1 sampai dengan 5.

Kontrol keperilakuan menunjukkan keyakinan mahasiswa terhadap profesi berwirausaha dan pemahaman mahasiswa terhadap profesi wirausaha. Kontrol keperilakuan merupakan hasil jumlah perkalian faktor yang menunjang tindakan dengan akses ke faktor kontrol tersebut. Pengukuran kontrol keperilakuan yang dirasakan sama seperti pengukuran sikap terhadap perilaku dan norma subjektif (Dharmmesta, 1998). Variabel kontrol keperilakuan diukur dengan 2 pernyataan mengenai keyakinan terhadap profesi wirausaha $(\mathrm{Ci})$ dan pemahaman terhadap profesi tersebut $(\mathrm{Pi})$. 
Teknik analisis data yang digunakan dalam penelitian adalah analisis regresi berganda dengan persamaan: $\mathrm{Y} 1=\alpha+\beta 1 \mathrm{X} 1+\beta 2 \mathrm{X} 2+\beta 3 \mathrm{X} 3+\varepsilon$, dimana Y1 adalah minat berwirausaha, $\mathrm{X} 1$ adalah sikap terhadap perilaku, X2 adalah norma subjektif dan X3 adalah kontrol keperilakuan. Uji $\mathrm{F}$ digunakan untuk mengetahui pengaruh simultan variabel sikap terhadap perilaku, norma subjektif dan kontrol keperilakuan terhadap minat mahasiswa untuk berwirausaha. Uji t digunakan untuk mengetahui pengaruh individual variabel independen tarhadap variabel dependen.

\section{HASIL DAN PEMBAHASAN}

\section{Deskripsi Responden}

Responden dalam penelitian ini dideskripsikan berdasarkan latar belakang orang tua dan pengetahuannya mengenai kewirausahaan. Hal ini diperlukan karena Sikap, norma dan kontrol perilaku mahasiswa tentunya tidak terlepas dari lingkungan dan pengetahuannya. Sehingga diperlukan juga deskripsi responden berdasarkan profesi orang tua dan pengetahuannya terhadap wirausaha. Tabel 1 menunjukkan profesi orang tua responden.

Tabel 1. Profesi Orang Tua

\begin{tabular}{ccc}
\hline Profesi & Jumlah & Persentase \\
\hline Wirausahawan/Pengusaha & 74 & $44,3 \%$ \\
Non Pengusaha & 93 & $55,7 \%$ \\
\hline Jumlah & 167 & $100 \%$ \\
\hline
\end{tabular}

Sumber: Hasil Olah Data

Data mengenai profesi orang tua menunjukkan bahwa mahasiswa yang mempunyai orang tua sebagai pengusaha sebesar $44,3 \%$ sedangkan mahasiswa yang profesi orangtuanya bukan pengusaha sebesar $55,7 \%$. Perbandingan jumlah tersebut termasuk seimbang, sehingga data yang diolah mewakili mahasiswa yang berada dalam lingkungan pengusaha dan mahasiswa yang berada dalam lingkungan bukan pengusaha. Untuk mengetahui pemahaman mahasiswa mengenai profesi wirausaha, maka responden juga ditanya mengenai apakah mereka sudah pernah menempuh mata kuliah kewirausahaan. Tabel 2 menunjukkan perbandingan jumlah mahasiswa yang sudah menempuh MK kewirausahaan dan yang belum pernah menempuh MK kewirausahaan.

Tabel 2. Mata Kuliah Kewirausahaan

\begin{tabular}{|c|c|c|}
\hline Keterangan & Jumlah & Persentase \\
\hline Pernah Menempuh MK Kewirausahaan & 141 & $84,4 \%$ \\
\hline $\begin{array}{l}\text { Belum Pernah Menempuh MK } \\
\text { Kewirausahaan }\end{array}$ & 26 & $15,6 \%$ \\
\hline Jumlah & 167 & $100 \%$ \\
\hline
\end{tabular}

Sumber: Hasil Olah Data

Responden dalam penelitian ini mayoritas sudah menempuh MK Kewirausahaan. Hal ini berarti responden yang mengisi kuesioner sesuai dengan yang dituju, yaitu responden yang secara teori memahami profesi sebagai wirausahawan. Dengan kondisi 
ini maka diharapkan jawaban responden menjadi lebih objektif. Karakteristik responden lain yang diidentifikasi adalah semester yang telah ditempuh. Semester ini menunjukkan berapa lama mahasiswa telah belajar di perguruan tinggi. Lama belajar akan menentukan pilihan profesi yang akan dijalaninya nanti. Tabel 3 menunjukkan deskripsi responden berdasarkan lama belajar atau berada di semester berapa responden tersebut saat mengisi kuesioner.

Tabel 3. Lama Studi Responden

\begin{tabular}{|c|c|c|}
\hline Semester & Jumlah & Persentase \\
\hline Semester 2 & 7 & $4,2 \%$ \\
\hline Semester 4 & 26 & $15,6 \%$ \\
\hline Semester 6 & 48 & $28,7 \%$ \\
\hline Semester 8 & 66 & $39,5 \%$ \\
\hline Diatas semester 8 & 20 & $12 \%$ \\
\hline Jumlah & 67 & $100 \%$ \\
\hline
\end{tabular}

\section{Hasil Uji Hipotesis}

Hipotesis yang diajukan dalam penelitian ini diuji menggunakan analisis regresi berganda. Penerimaan hipotesis diuji dengan uji F, uji t dan uji koefisien determinasi.

Hasil Uji F. Uji F digunakan untuk mengetahui pengaruh simultan beberapa variabel independen terhadap variabel dependen. Uji $\mathrm{F}$ dalam penelitian ini digunakan untuk mengetahui pengaruh simultan variabel Sikap terhadap Perilaku, Norma Subjektif dan Kontrol Keperilakuan terhadap Minat Mahasiswa untuk Berwirausaha. Hasil uji F tercantum dalam tabel berikut ini:

Tabel 4. Hasil Uji F

\begin{tabular}{llllll}
\hline \multicolumn{1}{c}{ Model } & \multicolumn{1}{c}{$\begin{array}{l}\text { Sum of } \\
\text { Square }\end{array}$} & df & Mean Square & F & Sig. \\
\hline 1 Regression & 24.353 & 3 & 8.118 & 10.175 & 0.000 \\
Residual & 81.803 & 163 & 0.502 & & \\
\hline Total & 106.156 & 166 & & & \\
\hline
\end{tabular}

Sumber: Hasil Olah Data

Hasil uji $\mathrm{F}$ menunjukkan bahwa nilai $\mathrm{F}$ sebesar 16,175 dengan signifikansi 0,000. Hasil tersebut mengindikasikan bahwa semua variabel independen secara simultan mempengaruhi variabel dependen. Hal itu terjadi karena nilai signifikansi di bawah 0,05. Hasil ini berarti penelitian ini berhasil membuktikan pengaruh simultan variabel sikap terhadap perilaku, norma subjektif dan kontrol keperilakuan terhadap minat mahasiswa untuk berwirausaha.

Hasil Uji t. Uji t digunakan untuk menguji pengaruh parsial variabel independen terhadap variabel dependen. Uji t juga digunakan sebagai dasar untuk penerimaan hipotesis yang diajukan. Hasil uji t disajikan dalam tabel 5.10 berikut ini: 
Tabel 5. Hasil Uji t

\begin{tabular}{lrll}
\hline \multicolumn{1}{c}{ Variabel } & $\mathrm{t}$ & $\mathrm{sig}$ & \multicolumn{1}{c}{ Keterangan } \\
\hline Konstanta & 8,605 & 0,000 & \\
Sikap & 1,566 & 0,119 & Tidak signifikan \\
Norma Subjektif & 3,050 & 0,003 & Signifikan \\
Kontrol keperilakuan & 2.010 & 0,046 & Signifikan \\
\hline
\end{tabular}

Sumber: Hasil Olah Data

Hasil uji menunjukkan bahwa dari tiga variabel independen, yaitu sikap terhadap perilaku, norma subjektif dan kontrol keperilakuan hanya dua variabel yang signifikan yaitu norma subjektif dan kontrol keperilakuan. Hal ini berarti hipotesis yang dapat diterima dalam penelitian ini adalah $\mathrm{Ha} 2$ dan Ha3. Sedangkan hipotesis pertama yang menyatakan sikap terhadap perilaku mempengaruhi minat berwirausaha tidak dapat diterima dalam penelitian ini.

Uji Koefisien Determinasi. Uji koefisien determinasi digunakan untuk mengetahui besarnya variabilitas dalam variabel dependen yang dapat dijelaskan oleh variabel independen. Uji koefisien determinasi menggunakan $\mathrm{R}^{2}$. Angka dalam $\mathrm{R}^{2}$ menunjukkan besarnya variabiliatas variabel dependen yang dapat dijelaskan oleh variabel independen. Hasil uji koefisien determinasi dicantumkan dalam Table 6.

Tabel 6. Hasil Uji Koefisien Determinasi

\begin{tabular}{ccccc}
\hline Model & Nilai $\mathrm{R}$ & Nilai $^{2}$ & Adjusted $\mathrm{R}^{2}$ & Standar Error \\
\hline 1 & 0,479 & 0,229 & 0,215 & 0,708 \\
\hline
\end{tabular}

Sumber: Hasil Olah Data

Hasil uji koefisien determinasi menunjukkan bahwa nilai $\mathrm{R}^{2}$ sebesar 0,229 , yang berarti perubahan dalam minat mahasiswa untuk berwirausaha dapat dijelaskan oleh sikap terhadap perilaku, norma subjektif dan kontrol keperilakuan sebesar 22,9\%. Hasil ini menunjukkan nilai yang kecil, karena variabel independen hanya mampu menjelaskan perubahan dalam variabel dependen kurang dari 30\%. Hal ini berarti minat mahasiswa untuk berwirausaha dapat dipengaruhi oleh faktor lain yang tidak diteliti dalam penelitian ini.

\section{Pembahasan Hasil Penelitian}

Berdasarkan hasil olah data yang dilakukan maka hasil penelitian ini menunjukkan bahwa sikap terhadap perilaku mempengaruhi minat mahasiswa untuk berwirausaha tidak dapat diterima. Dalam arti hasil penelitian ini tidak dapat membuktikan bahwa sikap terhadap perilaku berwirausaha tidak mempengaruhi minat mahasiswa untuk berwirausaha. Implikasi dalam penelitian ini adalah perspesi mahasiswa terhadap perilaku berwirausaha tidak mempengaruhi minat mahasiswa untuk berwirausaha. Dengan demikian minat berwirausaha pada mahasiswa di kota Yogyakarta tidak dipengaruhi oleh sikap terhadap perilaku. Hal ini bertentangan dengan penelitian yang dilakukan Ranto (2011). Perbedaan tersebut dapat terjadi karena perbedaan karakter responden dalam penelitian ini dengan responden dalam penelitian Ranto (2011). Responden penelitian ini adalah mahasiswa 
manajemen baik yang sudah menempuh mata kuliah kewirausahaan maupun yang belum menempuh mata kuliah kewirausahaan. Sedangkan penelitian Ranto (2011) menggunakan sampel mahasiswa yang sudah menempuh mata kuliah kewirausahaan. Demikian juga hasil penelitian ini berbeda dengan hasil penelitian Ditya dan Ikaputra (2011), di mana penelitian tersebut juga mengambil sampel yang sifatnya sangat lokasinya, yaitu sampel mahasiswa jurusan manajemen UPI bandung. Pengambilan responden yang bersifat lebih umum ternyata menimbulkan perbedaan hasil penelitian.

Hasil olah data menunjukkan bahwa Norma Subyektif mempengaruhi minat mahasiswa berwirausaha dapat diterima dalam penelitian ini dengan nilai t sebesar 3,050 dan tingkat signifikansi sebesar 0,003. Hasil penelitian ini mempunyai implikasi bahwa minat berwirausaha pada mahasiswa dipengaruhi oleh norma yang berlaku di sekitarnya. Apabila norma yang berlaku di lingkungannya menyatakan bahwa profesi wirausahawan menjanjikan kesuksesan maka mereka mempunyai minat untuk berwirausaha, demikian sebaliknya. Hasil ini sesuai dengan penelitian yang dilakukan Putra (2012) yang menyebutkan bahwa faktor yang pertama kali mempengaruhi minat berwirausaha adalah lingkungan. Demikian juga penelitian Ranto (2011) yang menyatakan bahwa norma subjektif mempengaruhi minat berwirausaha. Demikian juga penelitian Koranti (2013) yang menyatakan bahwa minat berwirausaha dipengaruhi oleh lingkungan keluarga dan faktor eksternal.

Variabel Kontrol Keperilakuan terbukti mempengaruhi minat mahasiswa untuk berwirausaha dalam penelitian ini. Hasil uji t terhadap pengaruh kontrol keperilakuan menunjukkan nilai t sebesar 2.010 dengan tingkat signifikansi 0,046. Impilkasi dari penelitian ini adalah persepsi kemudahan untuk menjalani profesi sebagai wirausahawan mempengaruhi minat untuk berwirausaha. Apabila mahasiswa beranggapan bahwa berwirausaha itu mudah, maka dia akan mempunyai minat untuk berwirausaha, demikian sebaliknya. Hasil penelitian ini sesuai dengan penelitian yang dilakukan Ranto (2011) yang menyatakan bahwa kontrol keperilakuan mempengaruhi minat mahasiswa untuk berwirausaha. Penelitian yang dilakukan Koranti (2013) menyatakan bahwa apabila rasa percaya diri mahasiswa tinggi, maka mahasiswa akan berasumsi bahwa berwirausaha itu mudah, dan mereka berminat untuk berwirausaha. Sedangkan mahasiswa yang tingkat kepercayaan dirinya rendah, akan beranggapan bahwa berwirausaha itu tidak mudah, sehingga mereka juga tidak berminat untuk berwirausaha.

\section{SIMPULAN DAN SARAN}

\section{Simpulan}

Setelah dilakukan proses olah data, maka kesimpulan dalam penelitian ini adalah:

1. Sikap terhadap perilaku tidak terbukti mempengaruhi minat untuk berwirausaha, karena nilai signifikansi hasil uji t menunjukkan angka diatas 0,05 . Hal ini berarti berdasarkan hasil penelitian dapat dinyatakan bahwa sikap terhadap perilaku tidak mempengaruhi minat mahasiswa untuk berwirausaha.

2. Norma subjektif mempengaruhi minat untuk berwirausaha dapat diterima, karena nilai signifikansi hasil uji t di bawah 0,05 . Hal ini berarti dapat dikatakan bahwa norma subjektif mempengaruhi minat mahasiswa untuk berwirausaha.

3. Kontrol Keperilakuan mempengaruhi minat untuk berwirausaha dapat diterima, 
karena nilai signifikansi uji t menunjukkan angkat di bawah 0,05 . Hal ini berarti dapat dikatakan bahwa kontrol keperilakuan mempengaruhi minat mahasiswa untuk berwirausaha.

\section{Saran}

Penelitian ini dilaksanakan dengan cara survey yaitu menyebarkan kuesioner untuk mahasiswa manajemen. Sampel yang membatasi pada mahasiswa manajemen menyebabkan hasil penelitian tidak mewakili aspirasi responden yang tidak berasal dari jurusan manajemen. Sehingga untuk penelitian selanjutnya disarankan untuk:

1. Memperluas sampel penelitian ke mahasiswa di luar jurusan manajemen. Sehingga hasil penelitiannya dapat diperbandingkan.

2. kendala yang menyebabkan banyaknya sampel antar perguruan tinggi tidak sama. Ada perguruan tinggi yang respondennya banyak, ada yang bahkan hanya satu. Untuk selanjutnya disarankan agar peneliti berikutnya memperhatikan sebaran asal responden.

3. Hasil uji koefisien determinasi yang hanya $22 \%$ menunjukkan bahwa masih banyak variabel yang dapat mempengaruhi minat berwirausaha, sehingga peneliti berikutnya diharapkan menambahkan variabel independen yang terkait dengan kepribadian responden. Misalnya dilihat tingkat kepercayaan diri, atau profesi orangtua.

\section{Keterbatasan}

Berdasarkan proses penelitian dan hasil olah data, dapat diidentifikasi beberapa keterbatasan dalam penelitian ini:

1. Sampel penelitian hanya mengambil mahasiswa jurusan manajemen. Fokus pada satu jurusan menyebabkan hasil penelitian menjadi terbatas, yaitu jawaban responden hanya mewakili mahasiswa manajemen.

2. Pengambilan sampel yang hanya mempertimbangkan kemudahan jangkauan menyebabkan jumlah responden antar perguruan tinggi tidak seimbang, ini memungkinkan terjadinya bias dan juga menjadi tidak universal, karena tingkat keterwakilan perguruan tinggi tidak sama.

\section{REFERENSI}

Ajzen, Icek, dan Martin Fishbein. 1968. Theory of Planned Behavior., www.gobooke.org. Diakses tanggal 26 November 2013.

Ajzen, Icek, dan Martin Fishbein. 1980. Understanding Attitude and Predicting Social Behavior. www.wikipedia.org. Diakses tanggal 26 November 2013.

Dharmmesta, B.S. 1998. Theory of Planned Behavior dalam Penelitian Sikap, Niat dan Perilaku Konsumen. Kelola Gadjah Mada Business Review. No.18, Th VII hal $85-103$.

Dharmmesta dan Handoko, 2000, Manajemen Pemasaran, Analisa Perilaku Konsumen, Edisi Pertama, BPFE, Yogyakarta. 
Ditya, Gallyn, M., dan Ika Putra Waspada. 2011. Faktor-Faktor Yang Mempengaruhi Minat Berwirausaha Mahasiswa Universitas Pendidikan Indonesia. Jurnal UPI, Vol. 06, No. 2, Nov 2011.

Koranti, Komsi. 2013. Analisis Pengaruh Faktor Internal dan Faktor Eksternal terhadap minat berwirausaha. Proceeding PESAT (Psikologi, Ekonomi, Sastra, Arsitektur \& Teknik Sipil) Vol. 5 Oktober 2013. Bandung, 8-9 Oktober 2013 ISSN: $1858-2559$.

Kuncoro, M. 2003. Metode Riset Untuk Bisnis dan Ekonomi: Bagaimana Meneliti dan Menulis Tesis. Erlangga, Jakarta.

Putra, Rano, Adita. 2012. Faktor-Faktor Penentu Minat Mahasiswa Manajemen Untuk Berwirausaha (Studi Mahasiswa Manajemen FE Universitas Negeri Padang). Jurnal Manajemen. Volume 01, Nomor 01, September 2012.

Ranto, Dwi, Wahyu, P. 2011. Aplikasi Theory of Planned Behavior dalam Penelitian Sikap-niat Berwirausaha pada Mahasiswa PTS di Yogyakarta. Prociding. Seminar Kopertis Wilayah V Yogyakarta.

Zaiyad, Habib dan Tjahyono H.K.. 2007. Aplikasi Theory Of Planned Behavior dalam Menentukan Sikap-Niat Siswa dan Siswi SMA Swasta Yogyakarta untuk Melanjutkan Studi di Sebuah Perguruan Tinggi Swasta di Yogyakarta. Kajian Bisnis, Vol. 2 No. 1. Hal. $49-66$. 
